\title{
Relationships between value orientations of adolescents and motivational action conflicts
}

\author{
Hüseyin Çalışkan \\ Faculty of Education, Sakarya University, Sakarya, Turkey, \\ ORCID: 0000-0001-6849-1318
}

\author{
Çağla Karademir \\ Ereğli Faculty of Education, Zonguldak Bulent Ecevit University, Zonguldak, Turkey \\ ORCID: 0000-0002-0703-8883
}

\section{Turgay Öntaş ${ }^{1 *}$}

Ereğli Faculty of Education, Zonguldak Bulent Ecevit University, Zonguldak, Turkey ORCID: 0000-0003-2258-0862

Article history

\section{Received:}

27.03.2020

Received in revised form: 01.05.2020

\section{Accepted:}

04.05.2020

Key words:

Adolescent, value, value orientation, motivational action conflict
This study aims to examine the relationships between value orientations and motivational action conflicts of adolescents and to determine how the value orientations predict motivational action conflicts and motivational action conflicts predicts value orientations. The research was carried out within the framework of the crosssectional screening model. The research group consists of $833(50.9 \%$ girls, $49.1 \%$ boys) students who are studying in different types of high schools (Science High School, Anatolian High School, High School, and Technical High School) in Kocaeli province. In research, the "Value Orientations Scale" and the "Motivational Action Conflict Scale" have been used as data collection tools. As a result of the research, there were significant relationships between value orientations and motivational action conflict. In conflict, which constitutes a conflict of motivational action, the decision was made as a result of learning, studying and leisure time meaningfully predicts achievement value orientations. It was also found that decision, learning, studying and leisure time in conflict significantly predicts well-being value orientations. It has been determined that achievement and well-being value orientations significantly predict decisions in conflict. Again, achievement and well-being value orientations are found to be a meaningful predictor of learning/studying. Besides, achievement and well-being have resulted in value orientations meaningfully predicting leisure time. Value orientations and motivational action conflicts in adolescents are proposed to be studied experimentally and with different variables as well.

\footnotetext{
${ }^{1 *}$ Correspondence: turgayontas@gmail.com
} 


\section{Introduction}

Adolescence, defined as the transition period between childhood and adulthood (Santrock, 2012/2014:16), which includes biological, cognitive, and socioemotional changes, includes individuals between 10 and 19 years of age according to the World Health Organization (WHO, 2007). During this period, there are many changes in cognitive, psychosocial, and physical development areas and adolescents need to adapt to these changes. From a psychosocial point of view, the adolescent is expected to have an identity at this stage (Erikson, 1997/2018). The main task of adolescents is to bring together the identities they bring from childhood with a more integrated identity (Miller, 2016/2017:216). Identity is a self-image consisting of many parts; vocational/career identity, political identity, religious identity, relational identity, achievement, intellectual identity, sexual identity, cultural/ethnic identity, physical identity, interests, personality (Soundtrack, 2012/2014). According to Robert Havinghurst (1974), one of the developmental tasks of adolescence is to acquire a set of values and moral systems that guide their behavior (Gander and Gardiner, 2004/2015:440; Yesilyaprak, 2018:44).

As the subject of values is a subject studied in many fields of social sciences such as philosophy, psychology, sociology, anthropology, history, many definitions and classifications (individual values, social values, national values, universal values, etc.) come across. According to Schwartz (2012:3), values are used to characterize cultural groups, societies, and individuals, monitor change over time and explain the motivational basis of attitudes and behaviors. Values are persistent beliefs exhibited in relation to a particular style of behavior or purpose of life, either individually or socially (Rokeach, 1973). When we think about our values, we think about what's important to us in life. Each of us has varying degrees of value (e.g., achievement, security, benevolence) (Schwartz, 2012:3). Values are the most critical intrinsic factors that shape our attitudes, beliefs, and actions, and serve as key criteria (Santrock, 2016). Values are determined motives that force the individual to choose specific goals from a variety of options (Ozguven, 1999). Values are frames of reference that set the ground for understanding and making sense of the individual and his / her environment, which influence preferences and attitudes and guide behaviors (Gungor, 1998; Yapici, 2009; Yapici, Kutlu and Bilican, 2012). Values are powerful regulators of human behavior because they are part of one's self-fiction and identity (Welzel and Inglehart, 2010). Values, unlike similar structures such as goals, attitudes or norms, do not have explicit references to purposes for specific behaviors, events, however, the values which people prefer and why because it lets you decide to avoid behaviors, events, and purposes are evaluated on the basis of compliance or noncompliance to the value system of the individual (Schwartz, 1992). Values correspond to the basic principles in human life; in line with these values, we prefer many behaviors to others, and forms of behavior that we adopt or do not adopt develop (Caliskur, 2008). If an action that leads to a particular goal is incompatible with the individual's value system, the individual likely experiences interpersonal conflict and ceases to pursue the goal, because the action has no motivational basis (Grund and Fries, 2018).

The dynamic structure of values, social structure changes, technological advances, and the differences in human interaction enables the exchange of value; it is observed that on change of the values of the individual factors (age, gender, and education) and environmental factors (family, mass media and geographical mobility), are effective (Emre, 2013). Ronald Inglehart (1977, 1990), who proposed the theory of change of value, based his views on Maslow's (1970) Hierarchy of Needs Theory, considered values as modern and postmodern values in two dimensions. According to the theory of value change, economic deprivation leads to a 
focus on low order needs such as livelihood and security needs, in other words, the development of modern values. Modern values include hard work, security, prosperity, achievement, determination, savings, and responsibility. Relying on achievement in modern values is the driving force of economic development and achievement is seen as the basis of modern values. In societies, as people's low order needs such as livelihood and security are met, as economic deprivation is eliminated, individuals tend to higher-order needs such as belonging and socialization, self-esteem, and self-realization, resulting in the development of postmodern values. Postmodern values include leisure choice, being with friends, satisfaction, and giving importance to leisure times. In Inglehart's conceptualization, postmodern values are happiness, self-actualization, and satisfying interpersonal relationships (such as leisure time, friends). These cover both the hedonic (maximization of satisfaction, minimization of pain) and the eudaimonic (realization of human potential) aspects of being good (Inglehart, 1977, 1990; Inglehart and Welzel, 2005).

Fries et. al, (2005) have used Inglehart's theory of value change, outlined above, to explain the values of today's adolescents. To this end, Fries et al, 2005 defined the value dimensions of achievement and well-being using the data of a qualitative survey conducted by Schmid et. al, 2005. The value dimensions of achievement and well-being are the core values of contemporary students, and they cover two major areas of student life: school and leisure time (Lens, Lacante, Vansteenkiste and Herrera, 2005). Achievement value orientation includes the importance of effort and achievement, appreciation of school-related issues, future goals, work, wanting to achieve certain things in life (Fries, Schmid, and Hofer, 2007). Succinctly, achievement value orientation describes the importance of students' efforts and achievements (Hofer, Schmid, Fries, Kilian, and Kuhnle, 2010). Well-being value orientation includes choosing social activities (leisure time activities), spending too much time with friends, loving fun and unplanned activities, wanting fun in life (Fries, Schmid, and Hofer, 2007). In short, well-being value orientation characterizes students' changing preferences towards leisure time and friends (Hofer, Schmid, Fries, Kilian and Kuhnle, 2010). Students can have both achievement value orientation and well-being value orientation at the same time (Hofer et al, 2007). In academic learning studies, it is necessary to understand the personal values of students, because personal values affect not only the academic task value but also the choice and participation of academic activities (Boekaerts et al., 2006, Fries et al., 2007).

Values to guide student behavior, in general, makes a decision in human life when achievement and well-being for all about to have interaction in their value orientation, it is inevitable at this point, the students are likely to experience motivational action conflicts (Fries et. al, 2005). Motivational variables have central importance in explaining experiences and behaviors (Grund, 2019:8). Motivation is a force that serves three functions: it animates or causes people to act, drives behavior toward achieving specific goals, and continues the effort to achieve those goals (cited from Steers and Porter, 1991 Riggio, 2018:189). In educational psychology, motivation typically refers to the values and motivational beliefs underlying a particular learning task or, more generally, learning (cited from Wentzel and Miele, 2016. Grund, 2019:8).

Where there are two or more action alternatives that offer positive incentives, but these action alternatives cannot be performed at the same time, conflict is defined as a motivational action conflict (Schmid, Fries, Hofer, Dietz, Reinders and Clausen, 2007). Motivational conflict refers to the immediate decision of which of the two or more activities that are intended to be carried out and which are opposite to each other (Hofer, 2007; Hofer et al., 2007). Studies on 
the subject (Hofer et al., 2007; Fries, Dietz, and Schmid, 2008; Hofer et al., 2009; Kuhnle et al., 2014) show that instead of motivational action conflict, the concept of motivational interference is also used. Fries, Schmid, Dietz, and Hofer (2005) base the approach to motivational action conflict on the personal origins of everyday action conflicts and assume that individual value orientations determine the probability of experiencing motivational action conflicts. Hence, the concept of motivational action conflict is explained in connection with individual value orientations. The concept of value orientations appears to be relevant to situations where opposing goals come into conflict (Boekaerts et al., 2006). According to Schmid et. al, (2005), daily action taken in terms of motivational characteristics and learning results of the conflict, a student, a similar action is not in accord with both values within the area, moves according to the relative importance of both value types.

There are 2 kinds of motivational interference in the school-leisure time conflict. One of these occurs during academic learning activities where students are affected by the incentives of leisure-time activities and are easily distracted or in a bad mood, have difficulty in continuing learning and work superficially. In another situation, students' academic learning activities with the incentive of their influencers, conflicting emotions and have difficulty in concentrating on leisure-time activities that occur during accusation fear (Hofer, 2007; Grund et. al, 2014; Hofer et. al, 2011; Kilian et. al, 2010a; Kilian et. al, 2010b; Chen, Teo, and Zhou, 2016).

Conflicts between academic and non-academic activities, also known as school-leisure time conflicts, are among the most common motivational conflicts (Hofer et al, 2009). Research results on the subject also reveal the relationship between value orientations of adolescents and motivational action conflicts. Many studies (Dietz, Hofer and Fries, 2007; Fries et al., 2005; Hofer et al., 2007; Hofer, Schmid, Fries, Zivkovic and Dietz, 2009) have concluded that achievement and well-being value orientations conflict with action options and lead to motivational action conflicts. Values enter the game when a person experiences a contradiction (conflict) between two options of equal importance that are at the center of their self (Verplanken and Holland, 2002). These studies have shown that students tend to choose the activity that is consistent with their value orientation, which is dominant in motivational action conflicts. Students with high achievement value orientation tended to make more decisions for the school-related alternative, while students with high well-being value orientation preferred the alternative for leisure time. Studies on the subject, show that students with a higher value of success orientation experienced less motivational interference after school-related activity decisions, but after the leisure-time related activity decisions, they have experienced more motivational interference. Conversely, students with a higher wellbeing value orientation experienced more motivational interference after a school-related activity decision, but they have experienced less motivational interference after a leisure-time related decision (Chen, Teo, and Zhou, 2016; Fries et. al, 2005; Hofer et. al, 2007; Hofer et. al, 2009; Hofer et. al, 2011; Kilian, Hofer, Fries, and Kuhnle, 2010a; Kilian, Hofer, and Kuhnle, 2010b).

In a longitudinal study with adolescents, the mutual effects of personal value orientations and motivational interference following school-leisure time conflicts were analyzed. On the one hand, success and well-being value orientations, on the other hand, motivational interference experiences during the study and leisure time in school-leisure time conflict were evaluated twice over 2 years. The relationships between these were investigated using multiple regression and path analysis. Motivational experience interference as a result of research, 
well-being value orientation and achievement of mutually predicts, however, while well-being value orientation is related to the motivational interference experience, the motivational interference is not related to well-being value orientation (Hofer, Schmidt, Fries, Kilian, and Kuhnle, 2010).

Studies on value orientations in Turkey show that their relationships with various variables are examined (Ateş-Bozdoğan, 2013; Karademir, 2015; Karademir and Iskender, 2019). There are studies such as internet addiction and value orientations (Dogan 2018), cyberbullying, parent relations, and value orientations (Nalbant, 2019), aggression and value orientations (Kaya, Ikiz, and Asici 2019), the value orientations of secondary school students (Kaya, Ikiz, and Asici, 2017; Turan and Kisac, 2015), the development of autonomy in adolescence (Ozdemir and Cok, 2011), the value orientations of secondary school students and the levels of autonomy (Sesli and Demir-Basaran, 2016). The Schwartz Values Scale, Portrait Values Scale, and Allport - Vermon-Lindzey Values Scale are used to determine value orientations in Turkey. The Fries, Schmid, Dietz, and Hofer (2005) scale, adapted into Turkish by Çalışkan and Karademir (2014), was used in this study. This study also examined the power to predict the motivational action conflicts.

\section{Aim}

This study aims to examine the relationships between value orientations and motivational action conflicts of adolescents and to determine how the value orientations predict motivational action conflicts and motivational action conflicts predicts value orientations.

\section{Method}

\section{Research Model}

The research was based on cross-sectional screening from general survey models. The cross-sectional scanning model is defined as an approach to measuring at a time (Fraenkel and Wallen, 2006) in accordance with the characteristics of the variables to be described in the research.

\section{Research Group}

The research group consisted of 833 secondary school students, 424 of whom (50.9\%) were girls, $409(49.1 \%)$ were boys, $33.7 \%$ were in ninth grade, $34.5 \%$ were in tenth grade and $31.8 \%$ were in eleventh grade. The students included in the research group were selected from different high school types (Science High School 33.7\%, Anatolian High School 34\%, High School 12\%, and Technical High School 20.3\%) to ensure maximum diversity in the sample. Students' ages range from 14 to 19, with an average age of 16 and a standard deviation of it is 88 .

\section{Data Collection Tools}

Two measurement tools were used as data collection tools in the research. The first is the "Value Orientations Scale", developed by Fries, Schmid, Dietz, and Hofer (2005) and adapted into Turkish by Çalışkan and Karademir (2014). The second is the "Motivational Action Conflict Scale", developed by Hofer, Schmid, Fries, Dietz, Clausen, and Reinders (2007) and again adapted into Turkish by Çalışkan and Karademir (2017). 


\section{Value Orientations Scale (VOS)}

The scale which measures individuals value orientations through two prototypes are in the form of the determinations of individual's orientation scale, and well-being value orientations, with two-factor four-point and determining the similarity of or the difference with this prototype with six ratings (ranging between looks a lot like me/and doesn't look anything like me). In the Turkish adaptation study, linguistic equivalence, explanatory, and confirmatory factor analyses were performed. All these analyses showed that the scale is a valid and reliable tool that measures two different value orientations (well-being and achievement value orientations). The test-retest reliability coefficient of the scale's wellbeing value orientation dimension was .86, the test-retest reliability coefficient of the achievement value orientation dimension was found as .83. The internal consistency and reliability coefficient calculated from the data of this study for both achievement and wellbeing value orientations was calculated as .74.

\section{Motivational Action Conflict Scale (MACS)}

It consists of three subscales (decision in conflict, learning/study, and leisure time) developed to investigate as accurately as possible the relationship between individuals' motivational action conflicts and their value orientations (achievement and well-being value orientations). On the scale, a short story has been used describing the concrete state of conflict that adolescents can experience. After the short story quadruple suites consist of 3 items and one-dimensional "conflict, the decision in the case of" sub-scale, then 11 positives, 4 negative, which is made up of 15 items in total, one-dimensional "learning/study" sub-scale consists of 7 items in total, 3 positive and 4 negative, and again one-dimensional "leisure time" sub-scales are given. The scale has been proven to be a valid and reliable tool by analyzing linguistic equivalence, exploratory and confirmatory factors in the study of Turkish adaptation. The test-retest reliability coefficient of Mecho's conflict decision subscale is .83, internal consistency coefficient is.60; learning / study motivational conflict experience subscale test-retest reliability coefficient is .83, internal consistency coefficient is .92 and leisure time motivational conflict experience subscale test-retest reliability coefficient is .77 , the internal consistency coefficient is .56. The internal consistency reliability coefficients calculated from the data of this study the decision in the conflict was .62, learning/study was .90 and leisure time was calculated as .58.

\section{Analysis of the Data}

For the study, the relationships between value orientations and motivational action conflicts of adolescents were examined using the Pearson Product-Moment Correlation Coefficient. Multiple regression analyses were used to determine the motivational action conflict of value orientations or the prediction levels of the value orientations of the motivational action conflict. The study also included descriptive statistics for related variables. In the analysis of the data .05 and .01 . levels of significance were based on. SPSS 21 statistical software was used in the analysis of the data. Also, before the analysis, whether there are end values and whether the regression analysis meets the assumptions of "linearity" and "multivariate normality" were analyzed over 860 data sets, and the assumptions of linearity and normality were satisfied by subtracting the end values and 27 data sets that violate the normal distribution.

\section{Findings}

In this section, the findings obtained as a result of the analyses carried out in the 
context of the purpose of the research are given.

Table 1. Correlation coefficients and descriptive statistics between value orientations and motivational action conflict

\begin{tabular}{llllll}
\hline Variables & $(1)$ & $(2)$ & $(3)$ & $(4)$ & $(5)$ \\
\hline (1) Success & 1 & & & & \\
(2) Well Being & $-.37^{* *}$ & & & & \\
(3) Decision in Conflict & $-.30^{* *}$ & $.41^{* *}$ & & & \\
(4) Learning / Studying & $-.40^{* *}$ & $.45^{* *}$ & $.56^{* *}$ & & \\
(5) Leisure Time & $.27^{* *}$ & $-.30^{* *}$ & $-.31^{* *}$ & $-.40^{* *}$ & 1 \\
\hline Average & 2.73 & 3.26 & 2.35 & 2.47 & 2.36 \\
SS & 1.18 & 1.22 & .64 & .62 & .36 \\
\hline
\end{tabular}

$\mathrm{N}=833 \quad * * \mathrm{p}<.01$

When we examine the correlation coefficients in Table 1 , between the achievement value orientation and decision in conflict and learning/study negative, in the leisure-time, positive direction of the mid-strength relations appears to be significant on the $\mathrm{p}<.01$ level. Besides, the conflict between decision and learning/study is positive, while the leisure time is in the negative direction of mid-strength relations $\mathrm{p}<.01$ level appears to be significant.

Table 2. Multiple regression results for the estimation of success value orientations

\begin{tabular}{lccccccccc} 
Model & B & SH & $\beta$ & $\mathrm{t}$ & $\mathrm{p}$ & $\mathrm{R}$ & $\mathrm{R}^{2}$ & $\mathrm{~F}$ & $\begin{array}{c}\text { Durbin- } \\
\text { Watson }\end{array}$ \\
& & & & & & & & & \\
\hline Constant & 3.59 & .38 & & 9.53 & .00 & & & & \\
Decision in Conflict & -.16 & .07 & -.09 & -2.31 & .02 & .43 & .18 & 61.38 & 1.93 \\
Learning / Study & -.58 & .08 & -.30 & -7.67 & .00 & & & & \\
Leisure Time & .40 & .11 & .12 & 3.56 & .00 & & & & \\
\hline
\end{tabular}

Adolescents were found to have a meaningful relationship with achievement value orientations of conflict resolution, learning/studying, and leisure time [R=43, $\left.R^{2}=18, p<.05\right]$. Accordingly, conflict resolution, learning/studying, and leisure time i.e. motivational action conflict describes $18 \%$ of the total variance in achievement value orientation. When standardized regression coefficients $(\beta)$ and t values are examined, the relative significance levels, respectively, learning/studying, leisure time, and motivational achievement orientation decision action in conflict, so the conflict can be said to be a significant predictor of value. The Durbin-Watson Test value of 1.93 also indicates that the errors are independent.

Table 3. Multiple regression results on the predictability of well-being value orientations

\begin{tabular}{llllllllll} 
Model & $\mathrm{B}$ & $\mathrm{SH}$ & $\beta$ & $\mathrm{t}$ & $\mathrm{p}$ & $\mathrm{R}$ & $\mathrm{R}^{2}$ & $\mathrm{~F}$ & $\begin{array}{c}\text { Durbin- } \\
\text { Watson }\end{array}$ \\
\hline Constant & 1.94 & .37 & & 5.21 & .00 & & & & \\
Decision in Conflict & .41 & .07 & .22 & 5.91 & .00 & .50 & .25 & 92.91 & 1.87 \\
Learning / Study & .55 & .07 & .28 & 7.35 & .00 & & & & \\
Leisure Time & -.42 & .11 & -.12 & -3.76 & .00 & & & & \\
\hline
\end{tabular}

Adolescents were found to have a meaningful relationship with well-being value orientations of conflict resolution, learning/studying, and leisure time $\left[\mathrm{R}=50, \mathrm{R}^{2}=25, \mathrm{p}<.01\right]$. Accordingly, conflict resolution, learning/studying, and leisure time, i.e., motivational action conflict well- 
being account for $25 \%$ of the total variance in value orientation. When the standardized regression coefficients $(\beta)$ and $t$ values are examined, it can be said that, as relative importance levels, learning/studying, leisure time, and conflict resolution, i.e., motivational action conflict, are a significant predictor of well-being value orientations. The DurbinWatson Test value of 1.87 also shows that errors are independent.

$\underline{\text { Table 4. Multiple regression results on decision estimation in conflict }}$

\begin{tabular}{llllllllll}
\hline Model & $\mathrm{B}$ & $\mathrm{SH}$ & $\beta$ & $\mathrm{t}$ & $\mathrm{p}$ & $\mathrm{R}$ & $\mathrm{R}^{2}$ & $\mathrm{~F}$ & $\begin{array}{c}\text { Durbin- } \\
\text { Watson }\end{array}$ \\
\hline Constant & 2.00 & .09 & & 21.85 & .00 & & & & \\
Success & -.09 & .02 & -.17 & -5.03 & .00 & .44 & .19 & 99.89 & 1.90 \\
Well being & .19 & .02 & .35 & 10.42 & .00 & & & & \\
\hline
\end{tabular}

The success and well-being value orientations of adolescents were found to have a significant relationship with the decision in conflict $\left[R=44, R^{2}=19, p<.01\right]$. Accordingly, success and well-being value orientations account for $19 \%$ of the variance in the decision in conflict. When standardized regression coefficients $(\beta)$ and $t$ values are examined, it can be said that the well-being and success value orientations, respectively, are a significant predictor of conflict resolution. The Durbin-Watson Test value of 1.90 also shows that errors are independent.

Table 5. Multiple regression results related to learning/studying

\begin{tabular}{llllllllll}
\hline Model & $\mathrm{B}$ & $\mathrm{SH}$ & $\beta$ & $\mathrm{t}$ & $\mathrm{p}$ & $\mathrm{R}$ & $\mathrm{R}^{2}$ & $\mathrm{~F}$ & $\begin{array}{c}\text { Durbin- } \\
\text { Watson }\end{array}$ \\
\hline Constant & 2.29 & .08 & & 27.13 & .00 & & & & \\
Success & -.14 & .02 & -.27 & -8.56 & .00 & .52 & .27 & 150.89 & 1.95 \\
Well being & .18 & .02 & .35 & 10.89 & .00 & & & & \\
\hline
\end{tabular}

The success and well-being value orientations of adolescents were found to have a meaningful relationship with learning/study $\left[\mathrm{R}=52, \mathrm{R}^{2}=27, \mathrm{p}<.01\right]$. According to this, success and well-being value orientations account for $27 \%$ of the variance in learning/studying. When standardized regression coefficients $(\beta)$ and $t$ values are examined, it can be said that the wellbeing and success value orientations, respectively, as relative importance levels, are a significant predictor of learning/studying. The Durbin-Watson Test value of 1.95 also indicates that the errors are independent.

Table 6. Multiple regression results on the predictability of leisure time

\begin{tabular}{llllllllll} 
Model & $\mathrm{B}$ & $\mathrm{SH}$ & $\beta$ & $\mathrm{t}$ & $\mathrm{p}$ & $\mathrm{R}$ & $\mathrm{R}^{2}$ & $\mathrm{~F}$ & $\begin{array}{c}\text { Durbin- } \\
\text { Watson }\end{array}$ \\
\hline Constant & 2.44 & .54 & & 45.52 & .00 & & & & \\
Success & .06 & .01 & .19 & 5.29 & .00 & .35 & .12 & 57.34 & 1.93 \\
Well being & -.07 & .01 & -.23 & -6.71 & .00 & & & & \\
\hline
\end{tabular}

The success and well-being value orientations of adolescents were found to have a significant relationship with leisure time $\left[\mathrm{R}=35, \mathrm{R}^{2}=12, \mathrm{p}<.01\right]$. Accordingly, success and well-being value orientations account for $12 \%$ of the variance in leisure time. When standardized regression coefficients $(\beta)$ and t values are examined, it can be said that the well-being and 
success value orientations, respectively, as relative importance levels, are a significant predictor of learning/studying. The Durbin-Watson Test value of 1.93 also indicates that the errors are independent.

\section{Conclusion, Discussion, and Suggestions}

The study aimed to examine the relationship between adolescent success and wellbeing value orientations and motivational action conflicts. Three important key results were obtained in the study.

The first of these are the results of the relationships between value orientations and the conflict of motivational action. It has been found to involve meaningful relationships between value orientations and motivational action conflict. It was determined that there were negative and positive relations between decision and learning/study in conflict with the success value orientation. Besides, there were no statistically significant relationships between well-being and conflict decision and learning/study in a positive and negative direction in leisure time. These findings are consistent with the research findings made on the subject. Students who value success, future goals, and hard work more often experience less motivational interference about school-related to-do work, while those who do experience more motivational interference after a decision on leisure time. On the contrary, after a decision related to school, students who have more value to leisure time and social activities experienced more motivational interference but after a decision related to leisure time, they experienced less motivational interference (Fries et. al, 2005; Dietz, Hofer and Fries, 2007; Hofer et. al, 2007; Hofer, Schmidt, Fries, Zivkovic and Dietz, 2009; Grund et. al, 2014, Hofer et. al, 2011, Kilian, Hofer, Fries, and Kuhnle, 2010a; Kilian, Hofer, and Kuhnle, 2010b; Chen, Teo, and Zhou, 2016). In a cross-section study, Fries and others (2008) found that as motivation confusion increased, an unselected task became more attractive to the learner. Moreover, there is experimental evidence of the effect of the eliminated option on the nature of the present behavior. Students who overestimate achievement enjoy meeting their friends less when a learning decision is suspended than students whose achievement is not high (Fries, Schmid, Dietz, and Hofer, 2005). Most studies on the subject (Hofer et al, 2007) do not allow conclusions to be drawn on the extent to which values affect the motivation variable since they use cross-sectional designs. The second and third basic results obtained in this study relate to the predictory roles of variables.

The second fundamental result obtained in this research relates to the role of motivational action conflict as a predictor of value orientations. In this result, achievement and well-being in itself are addressed towards value orientations. In conflict, which constitutes a conflict of motivational action, the decision was made as a result of learning, studying and leisure time meaningfully predicts achievement value orientations. It was also found that decision, learning, studying and leisure time in conflict significantly predicts well-being value orientations.

The third research result belongs to the role of value orientations as predictory on the motivational action conflict. This is examined in the context of conflict resolution, learning tutoring, and leisure time, which ultimately constitutes a conflict of motivational action in itself. It has been determined that achievement and well-being value orientations significantly predict decisions in conflict. Again, achievement and well-being value orientations are found to be a meaningful predictor of learning/studying. Besides, achievement and well-being have resulted in value orientations meaningfully predicting leisure time. The last two findings of 
the study are generally consistent with the findings of the longitudinal studies of Hofer, Schmid, Fries, Kilian, and Kuhnle (2010), which examined the interrelationship between motivational action conflict and value orientations.

When students face a conflict between school and leisure-time activities, they conflict when deciding, and this conflict leads to confusion during learning/studying and leisure time activities in connection with their value orientation. If we interpret the same situation in reverse, when students need to decide between school-leisure time activities and learning/studying, the motivational interference they experience during leisure time is related to their value orientation. This result supports the research findings related to the relationship between motivational action conflicts and value orientations (Chen, Teo, and Zhou, 2016; Dietz, Hofer and Fries, 2007; Fries et. al, 2005; Grund et. al, 2014; Hofer et. al, 2011; Hofer et. al, 2007; Hofer, Schmidt, Fries, Zivkovic and Dietz, 2009; Kilian, Hofer, Fries, and Kuhnle, 2010a; Kilian, Hofer, and Kuhnle, 2010b). Values to guide student behavior, in general, makes a decision in human life when achievement and well-being for all about to have interaction in their value orientation, it is inevitable at this point, the students are likely to experience motivational action conflicts (Fries et. al, 2005).

Research shows that school-leisure time conflict can have negative consequences on the issues of little time devoted to academic studies, academic deferral, poor academic satisfaction, poor academic performance, and a sense of academic helplessness (Hofer, 2007; Grund et al, 2014). School-leisure time conflict can lead to an academic postponement, defined as the conscious postponement of an intended course of action, although it is known that there are disadvantages to delay (Steel, 2007). Considering all these effects, it is important to do more study related to identity creation (Ericsson, 1997/2018) and potential motivational conflicts that adolescents may experience in the process of development of a system of values and morals (Gander and Gardiner, 2004/2015:440; Yeşilyaprak, 2018:44) that will guide their behavior.

\section{References}

Ateş-Bozdoğan, F. (2013). Analysis of value orientations of Anatolian teachers high school students in terms of some variables (Ankara case). Unpublished Master's Thesis. Gazi University Institute of Educational Sciences: Ankara.

Boekaerts, M., de Koning, E., \& Vedder, P. (2006). Goal-directed behavior and contextual factors in the classroom: an innovative approach to the study of multiple goals. Educational Psychologist, 41(1), 33-51. https://doi.org/10.1207/s15326985ep4101_5

Chen, P.- H., Teo, T., \& Zhou, M. (2016). Relationships between digital nativity, value orientation, and motivational interference among college students. Learning and Individual Differences, 50, 49-55. https://doi.org/10.1016/j.lindif.2016.06.017

Caliskan, H. \& Karademir, Ç. (2014). Adaptation of value orientations scale to Turkish. Journal of Values Education, 12(28), 47-68. Retrieved from http://dergipark.org.tr/en/pub/ded/issue/29170/312361

Caliskan, H. \& Karademir, Ç. (2017). The study of linguistic equivalence, validity, and reliability of the motivational action conflict scale. Sakarya University Journal of Education, 7(1), 20-33. https://doi.org/10.19126/suje.220184

Caliskur, E. A. (2008). The Relationship between the life values and personality traits of university students. Unpublished doctoral dissertation. Marmara University Institute of Social Sciences. 
Dietz, F., Hofer, M., \& Fries, P. (2007). Individual values, learning routines, and academic procrastination. British Journal of Educational Psychology, 77, 893-906. DOI: 10.1348 / $000709906 X 169076$

Emre, Y. (2013). Value orientations and religiosity in a changing world: the example of TRNC. Unpublished Master's Thesis. Çukurova University Institute of Social Sciences, Adana.

Erikson, E. H. (2018). 8 phases of man (3. bs). (G. Akkaya Çev.). Istanbul: Okuyan Us. (Publication date of original work 1997).

Fraenkel, J.R., \& Wallen, N.E. (2006). How to design and evaluate research in education. New York: McGraw-Hill.

Fries, P., Dietz, F., \& Schmid, P. (2008). Motivational interference in learning: The impact of leisure alternatives on subsequent self-regulation. Contemporary Educational Psychology, 33, 119-133. https://doi.org/10.1016/j.cedpsych.2007.10.001

Fries, P., Schmid, P., \& Hofer, M. (2007). On the relationship between value orientation, valences, and academic achievement. European Journal of Psychology of Education, 22, 201-216. https://doi.org/10.1007/BF03173522

Fries, P., Schmid, P., Dietz, F., \& Hofer, M. (2005). Conflicting values and their impact on learning. European Journal of Psychology of Education, 20(3), 259-274. https://doi.org/10.1007/BF03173556

Gander, M. J., \& Gardiner, H. W. (2015). Child and adolescent development (8. bs.). Bekir Onur (Prep. By). (A. Dönmez and H. N. Garland, Çev). Ankara: Imge Kitabevi Publications. (Publication history of the original work, 2004).

Grund, A., Brassler, N. K., \& Fries, P. (2014). Torn between study and leisure: how motivational conflicts relate to students' academic and social adaptation. Journal of Educational Psychology, 106(1), 242-257. https://doi.org/10.1037/a0034400

Grund, A. \& Fries, P. (2018). Understanding procrastination: a motivational approach. Personality and Individual Differences, 121, 120-130. https://doi.org/10.1016/j.paid.2017.09.035

Grund, A. (2019). Motivation and self-regulation. Bielefeld: Universität Bielefeld. DOI: 10.4119 / unibi/2939237

Gungor, E. (1998). Research on the psychology of values, Istanbul: Ötüken Publications.

Havighurst, R. J. (1974). Developmental tasks and education (3rd ed.). New York: McKay.

Hofer, M., Schmid, P., Fries, P., Zivkovic, I. \& Dietz, F. (2009). Value orientations and studying in school-leisure conflict: a study with samples from five countries. Learning and Individual Differences, 19(1), 101-112. https://doi.org/10.1016/j.lindif.2008.09.007

Hofer, M., Kuhnle, C., Kilian, B., Marta, E., \& Fries, P. (2011). Motivational interference in school-leisure conflict and learning outcomes: The differential effects of two value conceptions. Learning and Instruction, 21(3): 301-316. 10.1016/j.learninstruc.2010.02.009

Hofer, M. (2007). Goal conflicts and self-regulation: a new look at pupils' off-task behavior in the classroom. Educational Research Review, 2, 28-38. doi: 10.1016 / j.edurev.2007.02.002

Hofer, M., Schmid, P., Fries, P., Dietz, F., Clausen, M., \& Reinders, H. (2007). Individual values, motivational conflicts, and learning for school. Learning and Instruction, 17(1), 17-28. DOI:10.1016/j.learninstruc.2006.11.003

Hofer, M., Schmid, S., Fries, S., Kilian, B. \& Kuhnle, C. (2010). Reciprocal relationships between value orientation and motivational interference during studying and leisure. 
British Journal of Educational Psychology 80(4), 623-645. https://doi.org/10.1348/000709910X492180

Hofer, M., Schmid, P., Fries, P., Zivkovic, I. \& Dietz, F. (2009). Value Orientations and Studying in School-Leisure Conflict: a Study with Samples from Five Countries. Learning and Individual Differences, 19(1), 101-112. https://doi.org/10.1016/j.lindif.2008.09.007

Inglehart, R., \& Welzel, C. (2005). Modernization, cultural change, and democracy. New York: Cambridge University Press

Inglehart, R. (1977). The Silent Revolution: Changing Values and Political Styles Among Western Publics. Princeton, NJ: Princeton University Press.

Inglehart, R. (1990). Culture shift. Princeton: Princeton University Press.

Karademir, Ç. \& Iskender, M. (2019). The effect of psychological consultation and cognitivebehavioral approach-based group on adolescents' value orientations and motivational action conflicts. Ondokuz Mayis University Journal Of The Faculty Of Education, 38(2), 31-50. DOI: 10.7822 / omuefd.591589

Karademir, Ç. (2015). The effect of psychological consultation and cognitive-behavioral approach-based group on adolescents' value orientations and motivational action conflicts. Unpublished doctoral dissertation. Sakarya University Institute of Educational Sciences: Sakarya.

Kaya, Z., Ikiz, F., \& Asici, E. (2017). Analyzing the Value Orientations of High School Students in Terms of Various Variables. Dicle University Journal of Ziya Gökalp Faculty Of Education, (31), 662-674. https://doi.org/10.14582/DUZGEF.783

Kaya, Z., İkiz, F., \& Asici, E. (2019). Assessment of the level of aggression of adolescents in terms of value orientations, gender, and prediction of educational levels of parents. Kastamonu Journal Of Education, $27 \quad$ (1), 75-84. https://doi.org/10.24106/kefdergi.2306

Kisac, I. \& Turan, Z. (2015). Value orientations of secondary school students. Journal Of Values Education. 13 (29), 495-509.

Kilian, B., Hofer, M., Fries, P., \& Kuhnle, C. (2010a). The conflict between on-task and offtask actions in the classroom and its consequences for motivation and achievement. European Journal of Psychology of Education, 25(1), 67-85. https://doi.org/10.1007/s10212-009-0007-8

Kilian, B, Hofer, M. \& Kuhnle, C. (2010b). Value orientations as determinants and outcomes of conflicts between on-task and off-task actions in the classroom. Learning and Individual Differences, 20, 501-506. Doi: 10.1016 / j.lindif.2010.03.003

Kuhnle, C., Sinclair, M., Hofer, M., \% Kilian, B. (2014). Students' value orientations, intuitive decision making, and motivational interference, and their relations to regret. The Journal of Experimental Education, 82(3), 375-390. DOI: 10.1080 / 00220973.2013 .813363

Lens, W., Lacante, M., Vansteenkiste, M. \& Herrera, D. (2005). study persistence and academic achievement as a function of the type of competing tendencies. European Journal of Psychology of Education, 20, 275-287. https://doi.org/10.1007/BF03173557

Maslow, A. (1970). Motivation and personality. Brandies University. New York: Harper \& Row Publishers.

Miller, P. H. (2017). Theories of Developmental Psychology (2. bs.). Bekir Onur (Prep. by). (Z. Gültekin, Translated.). Ankara: Imge Kitabevi Publications. (Publication history of the original work, 2016). 
Nalbant, Z. N. (2019). Analysis of sensitivity to cyber bullying in adolescents in terms of relationships with parents and value orientations (Maltepe District Example). Unpublished Master's Thesis. Marmara University Institute Of Educational Sciences: Istanbul.

Özdemir, Y. \& Cok, F. (2011). Development of autonomy in adolescence. Turkish Psychological Counseling and Guidance Journal. 4 (36). 152-164.

Ozguven, I. E. (1999). Psychological Tests. Ankara: Sistem Offset.

Riggio, R. E. (2018). Introduction to Industrial and Organizational Psychology. (Translated by Literature Belkis Özkara). Ankara: Nobel.

Rokeach, M. (1973). The Nature of Human Values, New York: The Leisure Press.

Santrock, J. W. (2014). Adolescence (14. bs.). (D. M. Siyez, Translated by. Literature). Ankara: Nobel Publishing. (Publication date of original work 2012).

Santrock, J.W. (2016). Adolescence (16th ed.). New York, NY: McGraw-Hill Education.

Schmid, P., Fries, P., Hofer, M., Dietz, F., Reinders, H., \& Clausen, M. (2007). The Theory of Motivational Action Conflicts-Empirical Studies and Practical Consequences. In M. Prenzel (Ed.), Studies On The Educational Quality of Schools. The Final Report On The DFG Priority Programme. s. 317-331. Münster: Waxmann.

Schmid, P., Hofer, M., Dietz, F., Reinders, H., \& Fries, P. (2005). Value orientations and action conflicts in students" everyday life: an interview study. European Journal of Psychology of Education, 20(3), 243- 257. https://doi.org/10.1007/BF03173555

Schwartz, P. H. (2012). An overview of the Schwartz theory of basic values. Online Readings in Psychology and Culture, 2(1). http://dx.doi.org/10.9707/2307-0919.1116

Schwartz, P. H. (1992). Universals in the Content and Structure of Values: Theory and Empirical Test in 20 Countries. In M. Zanna (Ed.), Advances in Experimental Social Psychology, 25, 1-65. New York: Academic Press.

Sesli, C., \& Demir-Basaran, S. (2016). Examination of the relationship between value orientations and autonomy levels of secondary education students. Journal of The Institute of Social Sciences Of Mustafa Kemal University, 13 (34), 238-258.

Steel, P. (2007). The nature of procrastination: A meta-analytic and theoretical review of quintessential self-regulatory failure. Psychological Bulletin, 133(1), 6594. https://doi.org/10.1037/0033-2909.133.1.65

Verplanken, B., \& Holland, R.W. (2002). Motivated decision making: effects of activation and self-centrality of values on choices and behavior. Journal of Personality and Social Psychology, 82, 434-447. https://doi.org/10.1037/0022-3514.82.3.434

Welzel, C., \& Inglehart, R. (2010). Agency, values, and well-being: a human development model. Social Indicators Research, 97, 43-63. DOI: 10.1007/s11205-009-9557-z

World Health Organization [WHO]. (2007). Orientation program on adolescent health for health-care providers. Facilitator guide. New modules. Geneva: World Health Organization. Access address: https://www.who.int/maternal_child_adolescent/documents/pdfs/9241591269_op_han dout.pdf

Yapici, A.(2009). Globalization and the crisis of values. Journal of Values Education, 7, 1418.

Yapici, A., Kutlu, M. O., \& Bilican, F. I. (2012). Value orientations of teacher candidates. Journal of Electronic Social Science. 11 (42). 129-151

Yesilyaprak, B. (2018). Educational psychology development-learning-teaching (19. bs.). Ankara: Pegem Akademi. 